\title{
E. A. Poe and A. A. Shkljarevskij: Foregrounding Deduction and/or Social Commentary - A Comparative Study of Early Detective Fiction
}

\begin{abstract}
Three decades after American author Edgar Allan Poe laid down the foundations for the detective genre in the 1840s with his "tales of ratiocination," native detective stories began to appear on Russian literary scene. Among them were those written by Aleksandr Andreevich Shkljarevskij today known as "the father of Russian detective fiction." This article provides a short overview of Poe's literary influence as well as of the conditions that brought about the onset of Russian detective fiction. It offers an extensive comparative analysis of short stories by the mentioned "fathers" and identifies many similarities in their poetics. Finally, by looking into the characteristics of American Romanticism and Russian Realism that constitute the sociocultural backgrounds of the authors, it proposes answers to questions stemming from the difference in the aspect of analysis they emphasize.
\end{abstract}

Keywords: 19th century Russian detective fiction, Edgar Allan Poe, Aleksandr Andreevich Shkljarevskij, social criticism, ratiocination, crime fiction

\section{1.}

It is mostly accepted that the American author Edgar Allan Poe laid down the foundations for the detective genre by writing three short stories featuring an amateur investigator, C. Auguste Dupin: "The Murders in the Rue Morgue" in 1841, "The Mystery of Marie Rogêt" in 1842-43 and "The 
Purloined Letter" in 1844 (Thoms 133; Unrue 117; Dubose 1). Each of these stories has at its center a mysterious crime representing a challenging puzzle not only for the protagonist but also for the reader, who competes with him in gathering clues, aspiring to solve it before the narrative ends. Apart from the structure and content that would come to form the template of classic detective fiction, Poe introduced various concepts that were later developed further by authors who, in their own right, became milestones in the genre's evolution.

Poe's "tales of ratiocination," as he called them, reached France in the 1860 s, considerably influencing Emile Gaboriau and many others as they "raided his stories for ideas" (Messac 348-78; Knight, Crime Fiction 29). For instance, Gaboriau's best-known works, such as The Lerouge case ( L'Affaire Lerouge, 1866) featuring an amateur detective Le Père Tabaret, or his novels starring Tabaret's disciple policeman Lecoq, expanded on Poe's ideas of logical reasoning (Schutt 43) and displayed brilliant deductions of the protagonists (Knight, Crime Fiction 50). In England, the form pioneered by Poe was utilized by Wilkie Collins in his much celebrated The Moonstone in 1868 (Priestman 2), the novel T. S. Eliot called "the first and greatest of English detective novels" (412). Back in America, Anna Katharine Green mastered Poe's locked-room mystery formula in the long form with The Leavenworth Case in 1878 (Dubose 4), earning her the title of "The Mother of the Detective Novel" (Maida 1989). Most notably, Poe's formula of the eccentric but brilliant amateur detective, whose investigative process is chronicled by an admiring companion, was skillfully taken up by Arthur Conan Doyle and mirrored in his characters of Sherlock Holmes and Dr. Watson, first appearing in 1887's A Study in Scarlet. Poe's other devices include armchair detection, ${ }^{[1]}$ the innocent suspect, the in-plain-sight clue, the verbal clue (Dubose 2).

And while there is an abundance of material available on the topic of the genre's emergence in the United States, France and England, along with Poe's literary influence on various authors in those countries, as shown by the work of R. Messac (1929), D. H. Unrue (1995), S. Schutt (1998), M. Priestman (1998), M. H. Dubose (2000), P. Thoms (2002), S. Knight (2004), and many others, not much has been written on the same topic in Russia. Those that have studied Poe's influence in Russia, such as J. D. Grossman (1973) and V. Astrov (1942), focused primarily on defining the similarities between his artistic style and that of F. M. Dostoevskij while merely brushing upon the concepts related to the beginnings of detective fiction. Perhaps the reason for this lies in the 
general thought, even of its native 20th century researches - as Vladimir Razin has shown in his study $(2000)^{2]}$ - that Russia did not contribute to the development of detective fiction in its early stages; did not have any outstanding masters or ancestors in this precise field of literature. But what of the names such as Aleksandr Andreevich Shkljarevskij, whose fiction, as will be shown in this article, combines the elements of classic detective fiction with the tendencies of Russian Realism and incorporates the values of both? In fact, detective fiction arrived into Russia shortly after its spread through Western Europe. Gaboriau's ten novels were translated in the period between 1868 and 1874, followed by the translations of abovementioned novels by Collins and Green also shortly after their publication (Rejtblat, Ot Bovy 296). This literary process coincided with a number of momentous changes in Russia's social framework which generated favorable circumstances for the birth of Russia's indigenous detective fiction.

Namely, after Russia had suffered a defeat at Sevastopol and lost the Crimean War, tsar Alexander II, now aware of the country's disadvantages, introduced a series of Great Reforms, the most significant of which was the emancipation of serfs in 1861 (Daly 53). The reduction of nobility privileges and the elevation of common people's status followed. As a result the commercial and industrial expansion was accelerated and the capitalist development intensified (Mosse 71), propelling Russia into a new urbanized reality similar to that which gave rise to detective fiction in the West. With the publication of four Court Statues (sudebnye ustavy) in 1864, the principles of European public law were admitted into Russian legislation and greatly improved the country's judicial system (74). The hierarchy of courts was simplified, independent judiciary created, trial by jury introduced and all subjects proclaimed equal before the law (Daly 56-57). Trials were now open for public and became an event of great interest. They attracted spectators and journalists who published reports enabling the readers to closely follow the court proceedings (57). Moreover, journals, which have been reporting on criminal trials from abroad and polemicizing on the phenomenon of crime in Russian society (Whitehead 234), continued to discuss legal problems and sensational cases in skillfully written essays and articles (Rejtblat, Ot Bovy 297). This meant not only that fiction writers had before them an entirely new wellspring of ideas, but also that the readership was ripe and ready for their reception. Claire Whitehead showed that the role of polemical writing (publicistika) played a significant role as "a conduit between socio-historical factor 
and literary fictional production," influencing the practice of writing detective stories in the period between 1860s and 1880s (232). Equally relevant prerequisite was the founding of the institution of judicial investigators in early 1860s (235), which gave the potential authors an idea for a new literary protagonist. Thus, with the favorable conditions generated, the stage was set for the birth of native Russian detective novel. Although, the designation 'detective genre' was not yet used in classifying works of literature; instead the label 'crime fiction' was given to novels, novellas and short stories (ugolovnyj roman/povest'/rasskaz) dealing with felonies (Rejtblat, Ot Bovy 296). The "delivery" occurred in 1972, claims Abram Rejtblat, when three fictional works dealing with criminal investigation were published: Without a Trace (Koncy v vodu) by Nikolaj Dmitrievich Ahsharumov, Murder in Medveditsa Village: A Juridical Story (Ubijstvo v derevne Medvedice: Juridicheskaja povest') by Semjon A. Panov and Tales of an Investigator (Rasskazy sledovatelja) by Aleksandr Andreevich Shkljarevskij (298). Among these authors, Shkljarevskij achieved the greatest popularity and was a century later recognized as the father of Russian detective fiction (Rejtblat, Ot Bovy 298; Rejtblat, “Russian Gaboriau” 5; Shpilevaja 145; Shilova 35).

It was Rejtblat's essay titled “'Russian Gaboriau' or Dostoevsky's disciple?" ("'Russkij Gaborio' ili uchenik Dostoevskogo?") that served as the preface to the collection of Shkljarevskij's stories republished in 1993, which would motivate a handful of other researchers to publish articles on the same subject. G. A. Shpilevaja (2012) compared Shkljarevskij's works with those of Gaboriau, claiming they are the forefathers of police fiction. K. S. Overina (2013) treated Shkljarevskij's texts as the representative examples of Russia's 19th-century crime fiction and extracted several patterns to compare them with formulas (not) used by A. P. Chehov in his story "The Shooting Party" ("Drama na ohote"). S. A. Kibal'nik (2017) analyzed the correlations between Shkljarevskij's biography and his literary work and, lastly, Shilova (2019) using epistolary documents as the context for her research, underlined the influence of F. M. Dostoevskij on Shkljarevskij. While focusing on the topics introduced in Rejtblat's essay, the majority of researches seem to have forgotten about the very roots of detective fiction cultivated by Poe. Therefore, rather than comparing Shkljarevskij's stories with those of Gaboriau or Dostoevskij, this article aims to venture beyond the "mediators" and compare Shkljarevskij's stories with Poe's, who undoubtedly influenced Gaboriau's works and, as the article will attempt to show, left his mark on Dostoevskij's. 
An additional aim is to examine the literary tendencies of the period during which they wrote, with the purpose of, for example, linking Shkljarevskij's methods not to Dostoevskij but to a larger literary formation.

\section{2.}

The first translations of Poe's literary works, as indicated by Joan Delaney Grossman (1973), came to Russia via France, where the American was widely accepted due to residues of Romanticism and a liking for sensationalism. Thus, it is no wonder that Gaboriau as well found in his texts a source of inspiration. Poe's first literary work translated into Russian was "The Gold-Bug" ("Zolotoj zhuk," 1843) in 1847 (Osipova 142-43), which researchers defined as a cipher story (Niebuhr 22) and recognized in it the process of rational detection (Hayes 146). Ten years later "The Murders in the Rue Morgue" was translated and published in two March issues of literary magazine Son of the Fatherland (Syn otechestva), albeit under a different title - "Mysterious Murder" ("Zagadochnoe ubijstvo") (No. 11, 250-54; No. 12, 271-75). In other words, it was Poe's detective fiction that first saw light on the Russian literary marketplace, long before Gaboriau's. What is more, by the beginning of 1860 s there was already a substantial number of his other stories translated (Shaulov 243), and although two decades would pass until Poe received greater attention in Russia, another three of his stories were published in 1861 in the literary magazine Time (Vremja) edited by none other than Dostoevskij.

This great Russian writer even wrote an article in which he underlined that Poe often chooses to place his protagonists "in a most extraordinary outward and psychological situation, and, then, describes the inner state of that person with marvelous acumen, and amazing realism ${ }^{\not 3]}$ (230), something Dostoevskij would practice in his own literary masterpieces such as Crime and Punishment (Prestuplenie i nakazanie, 1866) or The Brothers Karamazov (Brat'ja Karamazovy, 1880). Dostoevskij marveled at Poe's competence to present "anything that is very unusual or has never before occurred and is only conceived as possible" so truthfully and "in all its details with such stupendous plasticity that you cannot but believe in the reality or possibility of a fact which actually never has occurred" (230-31). Any connoisseur of detective fiction would immediately in those lines recognize the words of Auguste Dupin: "The proper question in cases such as this, is 
not so much 'what has occurred?' as 'what has occurred that has never occurred before?'” (Poe, Selected 135,213$)$. The fact that Dostoevskij adopted one of Dupin's essential ideas and skillfully adapted it to express his admiration, shows that Poe and his detective fiction left quite an impression and stirred his productive impulses.

Along these lines, Grossman claims that Dostoevskij used Poe's story "The Tell-Tale Heart" as a model for certain aspects of Crime and Punishment. Namely, despite the fact they are not true classic detective stories because they reveal the murder's identity at the very beginning, "in both the converse side of the detection process is shown, as the reader wonders when and how the criminal will be broken down," both protagonists display self-sabotaging bravado, both make a confession following only a polite conversation with the police without being overtly interrogated (Grossman 51). On a similar note, Vladimir Astrov notices that "The psychological ratiocination as applied by the examining magistrate, Porfiry Petrovich, has much more of Poe's Monsieur Dupin than of the methods practiced by the real magistrates in those days" (72).

To summarize, both Gaboriau and Dostoevskij, whose literary works Shkljarevskij's have been linked to by several researches, were undoubtedly exposed to the influence of the same author Edgar Allan Poe. Therefore, the comparative analysis of similarities and differences in the approaches of two detective fiction "fathers," Poe and Shkljarevskij, seems invaluable. For this purpose three stories of each author have been chosen - "What motivated the murder? Tale of an investigator" ("Chto pobudilo k ubijstvu? Rasskaz sledovatelja"), "Tale of a Judicial Investigator" ("Rasskaz sudebnogo sledovatelja"), and "A Secret Investigation" ("Sekretnoe sledstvie") by Shkljarevskij and Poe's Dupin trilogy mentioned above. Due to the imbalance of material on their poetics, the priority will be given to Shkljarevskij and his stories. Since they are presumably less known to the readership, the article will include their summaries for the purpose of enabling better understanding.

\section{3.}

To begin with, both authors use titles indicative of the crime genre. However, while Poe underscores the words "murder," "mystery," and "theft," and is precise about either the location, person or object they refer to, Shkljarevskij stresses the question of motivation behind the 
unspecified murder and in each uses a term derived from the word "investigate," albeit with no exact names of persons or locations. Such fair degree of imprecision broadens the boundaries of text, enabling it to encompass a wider context; it renders an answer to a particular problem applicable in a number of others in their general points; it even implies individuality overshadowed by the anonymity of collectivism.

All stories except for "The Purloined Letter" begin and deal with murder. Because it is a unique crime "carrying an atavistic weight of repugnance, fascination and fear" and the ultimate crime since there can be no resurrection, the murder can capture the reader's attention and maintain his/her interest (James 5). As S. S. Van Dine instructs "no lesser crime than murder will suffice," especially if the text is lengthy. In each story the corpse is described in great detail with the aim of intensifying the necessity of revealing the culprit and the circumstances of the murder. As for the "The Purloined Letter," it is at least half in length compared to other stories and thus requires no murder to capture and hold the reader's attention.

In the introductory part of "The Murders in the Rue Morgue," the narrator speaks of the pleasure that disentangling enigmas brings to the analyst as well as of the skills he employs, for instance, in playing draughts and whist. The ability to identify with the opponent, the high quality of observation and the knowledge of what to observe are defined as essential. The introduction is then used not only to acquaint the reader with the skills Dupin will be employing in his investigation, but also to provide him/her with the necessary "apparatus" to join in the game of detection.

On the first pages of Shkljarevskij's "What motivated the murder?" a similar invitation is extended to the reader via the investigator's thoughts upon his arrival at the crime scene:

It's amazing how the most simple and ordinary things take on a different nature during criminal investigations. For instance, as I was walking through the hall, it seemed to me that the mirrors, the piano, and the armchairs looked at me differently than before; ... Every single thing in the office seemed to be saying: 'I witnessed a crime ... but I won't tell you what happened; I will look at you mysteriously and sternly until you figure it out on your own...' Take, for example, a knife, a nail, a glass... Today these things have only prosaic meaning, but if any of them were to be used as a murder weapon tomorrow, they would immediately stir something troubling in us $^{[4]}$ (Shkljarevskij 8) 
By accentuating that once they become a part of a crime scene objects acquire a different character, Shkljarevskij cautions that, should the reader join the investigation, he/she needs to be alert and observant of the details, as each of them might be the crucial piece of a puzzle. He also underlines that descriptive passages in detective fiction have a distinctive nature - not to serve as a device for stimulating profound associations of the subconscious mind like in other literary genres, but to function as a cogwheel in the clockwork mechanism of a detective story.

In the same manner that Poe provides an example of the analyst's ability to identify with another by illustrating how Dupin successfully traced the train of his companion's thoughts, so does Shkljarevskij give an example of deductive observation when his investigator enters the crime scene. Before us lies the room of a wealthy retired colonel, Valerian Konstantinovich Verhovskij, found stabbed to death. Following the inspection of the body the investigator notices an empty scabbard displayed on the wall rug, which seems to be, he notes, the perfect fit for the dagger used as the murder weapon. Having given an example of observation and deduction, he makes no further comments on the clue but leaves ample space for the reader to test his/her own deductive skill. We assume that the perpetrator did not plan the murder, but probably reached for the closest weapon as a result of strong emotional impulse. Indeed, the perpetrator will turn out to be Valerian's illegitimate son, Nikolaj Valerianov Hovskij, who committed the murder out of deepseated resentment for his father, combined with an instantaneous overwhelming need to protect the woman he considered his true mother. Shkljarevskij's observational method seems not only plausible but easier for the reader to master than Poe's method of identifying oneself with the criminal, which consequently makes Shkljarevskij's stories more accessible.

When explaining the analyst's methods, Poe's narrator also mentions the necessity of examining the countenance of those involved, their glances, their "every variation of face as the play progresses, gathering a fund of thought from the differences in the expression of certainty, of surprise, of triumph, or of chagrin" (Poe, Selected 120). And while an illustration of this method is given in Dupin's explanation of how he managed to read his companion's mind, it remains largely unimplemented in the investigation itself. The reader is deprived of the chance to observe the expressions and physiognomy of suspects, especially in "The Mystery of Marie Rogêt" where the entire investigation is conducted from the armchair. Instead, Dupin and his companion (and the 
reader) gather clues by reading excerpts from the local newspapers L'Etoile, Le Moniteur, Le Commerciel, etc.

Shkljarevskij, on the other hand, embraces the method listed by Poe's narrator. His judicial investigator notices the long and pale faces of footmen, maids and other household servants, including Valerian's valet Prokof'ich who was: "troubled, sorrowful and stood slumped with eyes sore and red from the tears he shed" (Shkljarevskij 8). On more than one occasion, he comments on the demeanor of Valerian's wife Antonina Vasil'evna and her two companions Avdot'ja Nikolaevna Kardamonova and Zhozefina Francevna Ljuseval'. These observations allow the reader to advance further in the game of deduction; to exclude certain suspects (e.g. Prokof'ich) while entertaining the guilt or at least the involvement of others.

The opportunity for this is provided for in Shkljarevskij's "A Secret Investigation" in which the sudden death of a young woman, Zinaida Aleksandrovna Mozharovskaja, firstly seen as related to her health problems, proves to be the result of poisoning. The murder was planned by her friend, Avdot'ja Nikanorovna Krjukovskaja, who was/is passionately in love with Zinaida's husband, Arkadij Nikolaevich. Although, Avdot'ja says nothing compromising when giving her first statement, the judicial investigator makes an observation of her physiognomy that makes him think of her "extremely passionate nature" (Shkljarevskij 84). Similarly, at the end of a lengthy passage on Mozharovskij's attractive features and noble manners, a brief note is given that: "something about him also made you think he was excessively kind, or rather, characterless, and could easily be wrapped around some clever schemer's finger ..." (84). Consequently, when Mozharovskij portrays Avdot'ja as an admirable woman, an attentive reader will not take his statement for granted but will detect the author serving him the "red herring." In other words, such observational remarks on the countenance, demeanor and physiognomy of characters seem to be essential for the reader's involvement in the investigation. Planted throughout the text they enable him/her to arrive at conclusions more easily than in Poe's stories where emphasis is placed on inanimate clues.

By choosing to put the characters rather than inanimate objects into the focus of investigation, Shkljarevskij broadens the text to include their personalities. He gives voice to almost each character; a voice that becomes "louder" and "steadier" proportionally to its owner's importance for the plot and depending on how far we are into the narrative. For instance, in "What motivated the 
murder?" the first round of conversations between the investigator and the members of Verhovskij household are either in dialogue form with almost equally distributed lines between interlocutors or the detective briefly retells the statements given, but as the plot progresses his presence diminishes. Such is the case after incriminating evidence is found in Antonina's and Zhozefina's rooms. The latter, having decided to correct her statement, asks "Where should I start? From yesterday when I saw the murder, or earlier, with the story of my life", the investigator answers: "The more you tell me about the circumstances of your life, ..., the better" (Shkljarevskij 20). Having invited Zhozefina onto the stage, the investigator almost completely removes himself from the text and she begins her story form the time she was orphaned but fortunate enough to be hired as a governess by a family moving to Russia. We find out she changed jobs many times and was constantly perused by men who gave her promises but always ended up deceiving her as she was frivolous and gullible. Thus she made herself a promise to change and secure her future by all means necessary. Her salvation came in the shape of Valerian Verhovskij, who, although married, arranged for her to move into his home where they continued their affair in secret. Therefore, when she, as was usual, came to his room in the middle of the night but stumbled on his corpse, she decided to hide her stained clothes and say nothing. Zhozefina's uninterrupted "confession" is an attempt at justification of her actions before both the investigator and the reader as it emphasizes the circumstances that shaped the personality of a woman who would rather choose to give a false testimony than have her social status compromised. In other words, the sociocultural context has significant importance in understanding the motives behind even a minor crime such as this. The reader is further assured of her story's credibility by yet another example of countenance observation: "Ljuseval's manners, which accompanied her testimony, the play of her physiognomy, the color of her face, the animation with a slight touch of cynicism, the air of sincerity in her words, made her testimony plausible, and I, suspicious as I am, believed her" (Shkljarevskij 24).

The same invitation to justify herself is extended to Antonina who, in spite of admitting to know the culprit's identity, chooses to keep it a secret even for the price of her own reputation and freedom. This invitation will instead be taken up by the murderer himself, who, fearing for Antonina's future, arrives at the investigator's door of his own accord. At this point, it becomes clear that Ljuseval's "confession" served only as a prelude to prepare the reader for the real confession of Nikolaj 
Valerianov. Instead of a few pages his will span over half of the story in total and include the chronicle of Verhovskij family as well as his own biography. We find out that Valerian married Antonina out of selfishness and had numerous affairs with other women, one of which was Nikolaj's birth mother, Lizaveta Dmitrievna. Good-hearted and childless Antonina, having found out about her husband's ailing illegitimate son, took the boy in and nurtured him back to health as he was her own. Nikolaj depicts his early childhood in the village with Antonina as the happiest time of his life, except for the contrasting "dark days" when Valerian threatened and beat him during his visits because the boy reminded him of the affair Lizaveta had with another man. Although she was instructed to leave Nikolaj in the village, Antonina continued to care for him in secret and even paid for his education by selling her dresses and jewelry as she had no other monetary resources. When he finished high school and moved to the same town, Valerian finally approved of him being a frequent guest but just as easily threw him out when Nikolaj confronted him for verbally and physically abusing Antonina. Thereby when Nikolaj came back to visit her, Antonina secretly led him inside the house. It was then that Valerian unexpectedly came home and Nikolaj was forced to hide underneath the bed. Listening to his drunken father abuse Antonina, he agonized over how to help her and finally "in my head from the chaos of my thoughts emerged the idea - to kill. 'Yes, to kill!' - I whispered decisively with spasmodic trembling hands as if answering my own question. And again - the previous chaos of thoughts! ... The noise and ringing filled my ears; my heart, it seemed, stopped beating; my hands went cold" (Shkljarevskij 41).

Nikolaj's confession displays not only the key elements that led him to commit the murder but show the analysis of Lizaveta's, Valerian's and Antonina's personalities based on information gathered from different sources; his own observations and interactions, their personal histories, letters and the statements of others. We gradually gain knowledge of Valerian being a multiple adulterer, an extreme egoist, a squanderer, an alcoholic, and ultimately a victimizer. Stated otherwise, the reader is subtly led through a separate deduction process aimed at defining Valerian's abuse of his wife and son as the crime that set the other one in motion. The confession then could be considered a detection story within a detection story, and Nikolaj with his analytic tendencies - a sort of detective in the covert one. But as opposed to the main investigation of the murder, this subtle investigation has sociocultural aspects in its general focus. For instance, it underlines the 
poor status of women in society, their economic dependence on and subjection to men, violence against women; it problematizes adultery as a common phenomenon and the neglect of illegitimate children. Bearing in mind that Shkljarevskij demonstrated his ability to employ deductive reasoning in the first half of the text successfully, one could almost claim that he led his judicial investigator to a dead-end on purpose and removed him from the stage so the culprit could reveal the sociocultural circumstances, personality-determinative factors and, perhaps, evoke compassion in the reader.

This is also visible in Shkljarevskij's "Tale of a Judicial Investigator," which opens up not with a crime but a commentary on a certain "social incident" - the separation of the local rich man, Arkadij Ivanych Pyl'nev, and his wife, Nastas'ja Pavlovna. The whole provincial town is occupied with passing judgment on Nastas'ja, using epithets such as "filthy" and "fallen" despite the fact that hardly anyone knows her. Soon thereafter, she is found strangled in St. Petersburg. The judicial inspector's search for material clues is once again intertwined with statements from those last in contact with the victim. Here the pattern of questioning has a ring composition, as it begins and ends with monumental confessions of Aleksandra Vasil'evna Lastova in the middle of which there are short interviews with three suspects. Lastova's first "confession" stretches over two out of eight chapters. In the form of an uninterrupted monologue, she admits that Nastas'ja was in fact her younger half-sister as they had the same father - a wealthy landowner who, upon entering marriage, ordered his illegitimate daughters to be sent away to a village, where they were to be "de-educated" into peasantry and forbidden from mentioning their parentage. After the emancipation of serfs, Aleksandra earned enough money to take her sister away from the household where she worked and protect her from the advances of men. Eventually, the older sister married Lastov, poor but a hard-working man with a bright future ahead, whilst the younger married Pyln'ev, a man who only inherited his wealth. The women were once again reeducated and instructed to hide their lowly past. However, mastering the manners and language of upper class proved difficult for Nastas'ja who committed errors at every step. Things were made more difficult by the fact that "the provincial beau-monde, in its essence, is much smaller than the Petersburg circle - obsessed with secular decency, and merciless in its condemnations... The wife's awkwardness upset her husband. ... Nasten'ka could lead a serious conversation on life's 
matters but was incapable of making small talk. And so the rumors began circulating that Nasten'ka is a fool with whom it was impossible to exchange sensible words" (Shkljarevskij 60). Her inability to fit in gradually caused her to withdraw into complete seclusion, even from her husband who, cruel as he was in his fits of jealousy and overall disappointment, claimed that if not for him, the sisters "would have become prostitutes; that taverns, beatings, illness, hospital, and finally death on the street or in an almshouse surely awaited them" (61). It was after he beat up Nastas'ja under the assumption she was having an affair that she finally escaped to St. Petersburg.

Lastova's "confession" is thus yet another example of a story within a story with a narrator who goes to great lengths to illustrate the behavior of characters; who provides fragments of dialogues and comments on the influence of milieu. By disclosing the real identity of her sister and what truly happened in Pyln'ev family, Lastova provides the reader with the solution to the mystery behind the "social incident" from the beginning of the story and in a way implies that Pyln'ev and the norms of higher class society are truly to blame for what happened to Nastas'ja. Prompted to tell the truth by new evidence, in her second confession she admits to have strangled her sister because there were rumors in circulation of her visiting taverns and being seen in the company of different men, which not only endangered Lastova's own reputation but made her extremely anxious about the future of her sister whom she deeply cared for: "Nasten'ka's death seemed at that moment the most humane end of her life. She would be delivered from what was foretold [by Pyln'ev] and, in my opinion, awaited her in reality" (79). Apart from the murderer then, the story exposes social issues similar to those in "What motivated the murder?" but with an emphasis on women's status (dependence on men) and the pressure to fit the mold prescribed by social norms. In illustrating the tendency to slander; the cruelty and vanity of upper class circles as well as their absurd practices which led Lastova to commit a murder rather than endure stigmatization of herself and her sister, Shkljarevskij takes on a role of social critic.

Moreover, the author's criticism is combined with a certain sense of compassion expressed via two elements - the investigator's empathy and the stories' closure. In "What motivated the murder?" the judicial investigator admits that he infinitely loves and respects Antonina, whose fate was strangely similar to that of his own mother in her youth and that, although he dealt with much 
complicated cases during his career, "none of them were so difficult" for him (27). Because he is considerate and protective of her, there is no actual interrogation. When Nikolaj reveals he killed Valerian the investigator, fearing Antonina would suffer even more, advises him to reconsider his confession. The last information we are given is that Nikolaj "cleverly slipped away in an unknown direction" (44). Similarly, in the "Tale of a Judicial Investigator" upon learning that Lastova turned to faith and was doing charity work, but transformed from an energetic woman to a pale entity weaker than a child, obviously tortured by her own consciousness, he feels deeply sorry for her and regrets not taking measures slower when confronting her. However, anxious to protect the reputation of her family, Lastova steals the crucial evidence (ring) and accuses the investigator of molesting her. As a result he is removed from the case and she is free to leave the country. In "A Secret Investigation", Krjukovskaja has half a year before the judicial investigator puts her biography together (which functions as the essential source of clues revealing the circumstances and motives behind the crime in Shkljarevskij's stories, as established by now) and finally apprehends her. The delayed arrest can be viewed as a sort of consolation for the woman who married a tyrant (whom she also poisoned) and suffered at the hands of a swindler and blackmailer, German Hristianovich Kebmezah, who "like a spider, entangled these two women [Krjukovskaja and her mother] in his webs from all sides" (100). The investigator's empathy and the closures of the three stories then imply that when judging a criminal, one should bear in mind that the individual is often a product of sociocultural circumstances, one that ought to be heard if anything is to be done about improving society. In other words, such closures suggest that Shkljarevskij considers social analysis to be of greater importance than the display of the arrest and the punishment of a criminal.

The endings of Poe's stories also lack the depiction of the culprit's apprehension but to the degree that the reader feels somewhat tricked. For instance, in "The Murders in the Rue Morgue" the killer turns out to be an escaped orangutan that learned how to use a razor by secretly watching his master shave. As Rosenheim states: “. . . no reader could reasonably be expected to include animals in a list of potential murderers" (81). Since the animal's owner is considered innocent, there is no actual human culprit. The investigation in "The Mystery of Marie Rogêt" focuses on defining the circumstances of the victim's disappearance and murder, while the killer's identity and 
motives seem to be secondary. Accordingly, the story ends with a note that: "This boat shall guide us, with a rapidity which will surprise even ourselves, to him who employed it in the midnight of the fatal Sabbath. Corroboration will rise upon corroboration, and the murderer will be traced" (Poe, Selected 248). Some readers see this denouement as disproportionate to the protracted narrative setup and therefore unsatisfying (Rosenheim 81). In "The Purloined Letter" Dupin's assignment is to find and steal back the letter from the Minister D who, at the end of the story, is only said to be awaiting his political destruction. It can be concluded that Poe, the same as Shkljarevskij, considers the apprehension and punishment of the criminal to be of little importance and instead underscores the very analysis. Nevertheless, the focus is not set on social analysis like in the works of the Russian author, but on the analytical process itself. The analysis has intrinsic value for Dupin, who is driven to investigate the cases precisely because they are insoluble for the police, while the monetary compensation seems to be a bonus. One could almost term his 'poetics' as "the analysis for analysis' sake". Unlike Shkljarevskij who takes the reader for an emotional roller coaster via the suspect's biography, Poe omits nearly all factors that could hinder ratiocination. Even when Dupin enters the mind of the sailor in "The Murders in the Rue Morgue", or Marie - the victim in the second story - their thoughts are rationally articulated without much emotion so as to allow pure analysis. The reader may be appalled by the state of the body or by the murder, but because the clues are provided via newspapers excerpts serving as a type of buffer zone between the suspects and the reader the latter is left with a "sober mind" and emotionally uninvested.

Furthermore, the detectives' physical exploits are few and in majority of cases relegated to the background in favor of the analytical aspect. Poe's protagonists spend most of their time analyzing newspaper reports and talking to each other or the prefect. Dupin does draw a pistol once (when facing the sailor in "The Murders in the Rue Morgue") but only to place it "without the least flurry, upon the table" (Poe, Selected 149) and hear the involved party confirm his theory. Similarly, his visit to Minister D's office and the stealing back of the purloined letter pass without any physical confrontation and emphasize Dupin's successful analysis of and identification with the Minister. Although he visits crime scenes more frequently than Dupin, the primary activity of Shkljarevskij's judicial investigator amounts to the passive listening of suspects to such an extent he could be called a different type of 'armchair detective.' In "A Secret Investigation" he employs the method of 
surveillance (solely because he is located across from Kebmezah by coincidence) and disguises himself only to once again become a passive listener as Atomanichenkov provides him with information on Kebmezah, crucial for the analysis of Krjukovskaja's actions. The search of premises or detaining of a criminal fall to the local police and are often summarized in a single sentence.

It is also in favor of the analytical aspect that neither of the authors elaborates on the identity of the detective. Although, Shkljarevskij could be said to have an additional reason; by designating his protagonist only as a judicial investigator with mediocre abilities and as flawed due to having "too much of what is called 'emotion'” (44), Shkljarevskij makes him not only equal to other people but a part of collective - the representative of those eager to understand and improve their society. Instead of elaborating on Dupin's personality and private life, Poe gives priority to the mathematical workings of his mind. Even his companion's main role is to encourage Dupin to reveal his ratiocinative feats and go on "very much as if in a soliloquy" (Poe, Selected 135), as well as to marvel at his brilliance, which additionally elevates the success of his analysis. Most of what we know of Dupin is related to his methodology. Poe endows him with an impeccable intuitive mind, precise deductive logic combined with artistic imagination and the ability to identify with the criminal, making him the ideal investigator, unique in his talent and superior even to the police prefect, all of which separates him from the mediocrity of official authorities. In fact, Dupin functions as the rationalist superhero challenged solely by the apparently inexplicable (Morse 98). That is also why his status of an amateur detective is crucial: he cannot waste time on everyday crimes which would "bore him and insult his intelligence" (98). In other words, rather than depicting the detective as a part of the collective, an ordinary man who investigates mundane crimes revealing the shortcomings of society like Shkljarevskij does, rather than showing imperfections that render one human, Poe prioritizes and advocates individualism and idealism both via his investigator and the story's plot.

\section{4.}

The reasons for the differences between the authors' methods can be traced to their cultural backgrounds, for people do not live in vacuum but are exposed to shifting trends and certain 
influences of society they live in. In this regard, the individualism and idealism evident in Poe's 'tales of ratiocination' can be said to mirror the characteristics of the American national mind and the Romantic movement in the 19th century.

Because America was settled by people who expected and yearned to improve their conditions, idealism became a trait of their national personality, which then reflected itself in their literature rich in idealistic expression (Darnall 186-87). It became the root of their philosophy which saw reality as existing "primarily in the ideal world—that is, in the mind-while the material world merely reflected that universe" (Phillips and Ladd 5). Idealism of romantics was also visible in their conviction that the human beings were capable of rising above their animal instinct and of governing their lives in accordance with higher principles of social equality, freedom, and human rights (5).

Individualism, on the other hand, found its utterance in the principle of "individual opportunity - that every man is entitled to life, liberty and the pursuit of happiness", in material, intellectual and spiritual independence, and in personal initiative of the authors who strived after originality and broke with past traditions (Darnall 188-89). Because human beings were seen as having strong will attached to spirit and mind, which also meant capable of appropriately using insight and imagination, the individual was seen as master of his fate, able to self-create and, thus, responsible for their situation in life which divorced him from the structural and institutional influences of society (Epstein 57). As Low says: "In no other try, has individualism been given such free play, or so molded the whole life of a people, as in America. In America society is nothing; the individual is everything" (qtd. in Darnall 188).

F. M. Darnall recognizes these traits of an American mind in Poe himself, for instance, in the fact that he "discarded the past traditions of poetry to venture into new fields and untrodden paths" (198). Accordingly, it can be said that Poe's protagonist who is unique in his eccentricity and deductive prowess and excels above all in solving mysteries, who shows intellectual independence and always strives for idealism represents the embodiment of such Americanism.

In Shkljarevskij's works, we can recognize the tendencies of Russian Realism, which reached its zenith between 1855 and 1880 and was characterized by civic involvement and intense compassion of the writers illuminating the images of mankind imprisoned by its own ideologies (Freeborn 248, 259). In fact, the themes of civic criticism were first introduced by Aleksandr 
Radishchev at the end of the 18th century (Andrew, Second Half ix-x). This tradition was then built upon by Pushkin, Lermontov and Gogol and still further developed by Turgenev, Dostoevskij, Tolstoj and Chekov (Andrew, Second Half ix-x). Especially influential was literary critic Vissarion Belinskij, whose views in the 1830s and 1840s on the social function of art and the involvement of the artist with society added much to the changes in the complexion of later 19th-century Russian literature (Andrew, Rise 114). Belinskij held that "The man of letters must necessarily be a critic of his society from the left ..." (Peace 190).

In 1855 yet another influential critic, Nikolaj Chernyshevskij published an essay "Aesthetic Relations of Art to Reality" (“Esteticheskie otnoshenija iskusstva k dejstvitel'nosti”). Stressing that literature should serve utilitarian purposes he, together with other radical critics, defined realism as "almost scientific description of the underside of existing social reality", interpreted the works of realists in this manner and encouraged those who wrote critically of present realities whilst pointing toward a better future (Freeborn 248, 259). Included in their doctrine was "a critique of the family and promotion of what we would now call feminism" (249), the themes that appear to be quite relevant in Shkljarevskij's tales.

Other groupings of intelligentsia of that time included the liberals, who sought their inspiration in the West, and the Slavophiles, the far-right wing advocating the return to the religious bases. Regardless of orientation, they all claimed "to speak for 'the people' (Freeborn 252-53), and not only the "thick journals" but the literature, which could not escape the political realities of the period, "served to reflect the[ir] ideas, illuminate them and transmit them, while also molding them and transforming them" (Freeborn 253, 256). Consequently, the realist literature depicted a multitude of characters, lives and relationships in great depth and the prevailing themes became "justice in human relations, in determining the degree of guilt between generations, between nations, between the criminal and the law" and as the concern with the inherent value of the individual grew - justice for the individual (Freeborn 257). The latter was the result of increasing awareness of scientific approaches to the study of human personality based on anthropological principles and the notion of human psychology as highly complex (Freeborn 257). Hence, the literature explored the experiences of individuals and sought to enfranchise not only the positive hero, but the murder, the outcast (Freeborn 257). Shkljarevskij, whose stories reveal the 
shortcomings of Russian society in the fates of his characters and problematize on justice for the individual from the empathic standpoint, clearly wrote under the influence of Realism.

\section{5.}

The analysis has shown that Shkljarevskij's approach to writing detective stories is similar to Poe's in many ways: the titles indicate their genre; the central crime is always murder in order to draw and maintain the reader's attention as well as stimulate him/her to join in the investigation. In the introductory part the author cautions the reader to be alert and observant of the details as they can serve as clues leading to the solution of the mystery, and then the example of deduction is provided. Shkljarevskij embraces Poe's idea - which remained largely unimplemented in his own tales - of carefully studying the countenance of characters, thus enabling the reader to make conclusions easier. The culprits are regularly revealed but their arrest is more of an exception than a rule because the authors foreground analysis (in Shkljarevskij's stories empathy is the additional factor). For the same reason neither of them elaborates on the identity of the investigator nor displays their physical exploits.

There is, however, a difference in the aspect of analysis they value. Whilst Shkljarevskij tackles sociocultural equations, Poe seems to value equations themselves. We listen to the narrator list the analyst's abilities; to Dupin analyze newspaper reports or prefect's findings, explain inanimate clues or the process of his own identification with either the criminal or the victim, whilst the priority in Shkljarevskij's stories is the mind of the suspect and the sociocultural context it reveals. It seems that the main quest of his judicial investigator amounts to assembling the fragments of the suspect's biography to gain insight into social influences that shaped their personality and the circumstances that led them to commit a crime. Or rather, to reveal the indirect culprit - society with its many issues such as violence against women, the pressure to fit the mold prescribed by social norms or be stigmatized, neglect of illegitimate children, etc.

But this difference in the authors' focus can be traced to their cultural backgrounds. Idealism and individualism evident in Poe's tales can be recognized as characteristics of the American national mind and the Romantic movement, while social criticism and compassion for the criminals, who are actually the victims of flawed society in Shkljarevskij's stories, can be ascribed to the poetics of 
Russian Realism. Some would perhaps say that by removing the detective from the text in favor of the culprit's elaborate confession Shkljarevskij tricked the reader; that the deductive game, which was supposed to provide mental exercise, was brought to a halt and failed. But one should refrain from viewing Russian literature completely through the prism of American standards and take into account that Russian authors of that period had a different priority - to critically view society. By illustrating the murder's background and sociocultural influences defining his/her actions, Shkljarevskij prompts the reader to contemplate on the situation and pose questions such as whether the crime would have happened at all if society was different; to what extent is the murderer really to be blamed; or even whether the reader would have done the same if in a similar position. In other words, he encourages the reader to take up an active and twofold role - to play the game of detection and to remain vigilant of social issues. The stories themselves are of dual nature as they combine mental and moral exercise; integrate both the devices introduced by Poe in his tales of "ratiocination" and the tendencies promoted by the authors and literary critics of Russian Realism.

\section{Works Cited}

Andrew, Joe. Russian Writers and Society during the Rise of Russian Realism. Palgrave Macmillan, 2014.

Andrew, Joe. Russian Writers and Society in the Second Half of the Nineteenth Century. Palgrave Macmillan, 2014.

Astrov, Vladimir. "Dostoievsky on Edgar Allan Poe." American Literature, vol. 14, no. 1, 1942, pp. 70-74.

Daly, Jonathan. Crime and Punishment in Russia: A Comparative History from Peter the Great to Vladimir Putin. Bloomsbury Academic, 2018.

Darnall, F. M. "The Americanism of Edgar Allan Poe." The English Journal, vol. 16, no. 3, 1927, pp. 185-92.

Dostoevskij, Fedor Mihajlovich. “Tri rasskaza Edgara Poe.” Vremja, Jan. 1861, pp. 230-31. 
Dubose, Martha Hailey. Women of Mistery: The Lives and Works of Notable Crime Novelists. Thomas Dunne Books, 2000.

Eliot, T. S. "Wilkie Collins and Charles Dickens." Selected Essays, 1917-32. Faber, 1932.

Epstein, M. William. The Masses are the Ruling Classes: Policy Romanticism, Democratic Populism, and Social Welfare in America. Oxford University Press, 2017.

Freeborn, Richard. "The Nineteenth Century: The Age of Realism, 1855-80." The Cambridge History of Russian Literature, edited by Charles E. Moser, Cambridge University Press, 2008, pp. 248-332.

Grossman, Joan Delaney. Edgar Allan Poe in Russia: A Study in Legend and Literary Influence (Colloquium Slavicum). Jal-Verlag, 1973.

James, P.D. Talking About Detective Fiction. Alfred A. Knopf, 2009.

Kibal'nik S. A. 2017. "'Sudebnyj sledovatel”' v Russkoj detektivnoj literature 1860—1880 gg. ot Aleksandra Shkljarevskogo do Chehova." RUDN Journal of Studies in Literature and Journalism, vol. 22, no. 3, pp. 384-97.

Knight, Stephen. "The Golden Age." The Cambridge Companion to Crime Fiction, edited by Martin Priestman, Cambridge University Press, 2003, pp. 77-94.

Knight, Stephen. Crime Fiction, 1800-2000, Detection, Death, Diversity. Palgrave Macmillian, 2004.

Maida, Patricia D. Mother of Detective Fiction: The Life and Works of Anna Katharine Green. Bowling Green State University Popular Press, 1989.

Messac, Régis. Le ‘Detective Novel' et l'Influence de la Pensée Scientifique. Champion, 1929.

Morse, David. American Romanticism, Volume 1: From Cooper to Hawthorne. Palgrave Macmillan, 1987.

Mosse, W. E. Alexander II and the Modernization of Russia. Collier Books, 1976.

Niebuhr, Gary Warren. Make Mine a Mystery: A Reader's Guide to Mystery and Detective Fiction. Libraries Unlimited, 2003. 
Osipova, El'vira. "O perevodah Edgara Po v Rossii." Literatura dvuh Amerik, no. 2, 2017, pp. 14155.

Overina, K. S. "'Drama na ohote' A. P. Chehova v kontekste russkogo ugolovnogo romana." Russkaja filologija, no. 24, 2013, pp. 71-79.

Peace, Richard. "The Nineteenth Century: the natural school and its aftermath, 1840 1855." The Cambridge History of Russian Literature, edited by Charles E. Moser, Cambridge University Press, 2008, pp. 189-247.

Phillips, Jerry, and Andrew Ladd, editors. Romanticism and Transcendentalism (1800-1860). Facts on File, 2006.

Poe, Edgar Allan. Selected Tales. Penguin Books, 1994.

Poe, Edgard [sic]. "Zagadochnoe ubijstvo." Syn Otechestva, no. 11, Mar. 1857, pp. 250-54; no. 12, March 1857, pp. 271-75.

Priestman, Martin. Crime Fiction from Poe to the Present. Northcote House, 1998.

Razin, Vladimir. V labirintah detektiva: ocherki istorii sovetskoj i rossijskoj detektivnoj literatury XX veka. E-book, 2000, detective.gumer.info/txt/razin.doc, Accessed 23 July 2020.

Rejtblat, A. I. "'Russkij Gaborio' ili uchenik Dostoevskogo?" Chto pobudilo k ubijstvu? (Rasskazy sledovatelja), edited by Aleksandr Shkljarevskij, Hudozh. lit. 1993, pp. 5-13.

Rejtblat, A.I. Ot Bovy k Bal'montu i drugie raboty po istoricheskoj sociologii russkoj literatury. Novoe literaturnoe obozrenie, 2009.

Rosenheim, Shawn. "Detective Fiction, Psychoanalysis, and the Analytic Sublime." Edgar Allan Poe's 'The Tell-Tale Heart' and Other Stories, edited by Harold Bloom, Bloom's Literary Criticism, 2009, pp. 81-103.

Schutt, Sita. "Rivalry and Influence: Nineteenth-Century French Detective Narratives." The Art of Murder, edited by Gustav Klaus and Stephen Knight, 1998, pp. 38-49.

Shaulov S. S. "Predislovie k publikacii 'Tri rasskaza Edgara Poe.”" Dostoevskij: Sochinenija, pis'ma , dokumenty: Slovar'-spravochnik. SPb, 2008, pp. 243-44. 
Shilova, Natal'ja Leonidovna. "Ob odnom literaturnom vlijanii: rasskaz 'otchego on ubil ih?' A. A. Shkljarevskogo i 'Zapiski iz mertvogo doma’ F. M. Dostoevskogo.” Uchenye zapiski

Petrozavodskogo gosudarstvennogo universiteta, vol. 178, no. 1, 2019, pp. 35-40.

Shkljarevskij, Aleksandr. Chto pobudilo k ubijstvu? Rasskaz sudebnogo sledovatelja. Sekretnoe sledstvie. RIC Literatura, Mir Knigi Ritejl, 2011.

Shpilevaja, Galina Aleksandrovna. "A. A. Shkljarevskij i E. Gaborio: rodonachal'niki "policeskogo" romana." Vestnik KGU im. N.A. Nekrasova, no. 5, 2012, pp. 145-49.

Thoms, Peter. "Poe's Dupin and the Power of Detection." The Cambridge Companion to Edgar Allan Poe, edited by J. Kevin Hayes, Cambridge University Press, 2002, pp. 133-48.

Unrue, Darlene Harbour. "Edgar Allan Poe: The Romantic as Classicist." International Journal of the Classical Tradition, vol. 1, no. 4, Spring 1995, pp. 112-19.

Van Dine, S. S. "Twenty rules for writing detective stories." American Magazine, Sept. 1928.

Whitehead, Claire. "Debating Detectives: The Influence of Publitsistika on Nineteenth-Century Russian Crime Fiction." The Modern Language Review, vol. 107, no. 1, Jan. 2012, pp. 230-58. 
[1] Detection conducted without the investigator personally visiting a crime scene or interviewing witnesses.

[2] Russian journalist and essayist, Vladimir Razin, passed away in 2000, before seeing his work (V labirintah detektiva: ocherki istorii sovetskoj i rossijskoj detektivnoj literatury XX veka) published. The book is based both on his analysis and on rich factual material, such as statements of and interviews with other authors (e.g. Lev Sergeevich Ovalov on censorship in Soviet Union and his arrest; Mihail Nikolaevich Alekseev on "front line writers" and his conversation with the editor who ordered the creation of reading material for the army), as well as newspaper articles unavailable today. Regardless of the fact that the book was left without the author's final edition, it represents a significant contribution to the studies in the field of crime/detective genre in Russia.

[3] The English translation of Dostoevskij's article is available in: Astrov 73-74.

[4] All excerpts from Shkljarevskij's tales are translated from Russian into English by the author of this article.

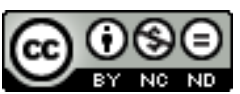

Creative Commons Attribution-NonCommercial-NoDerivatives 4.0 International License 